\title{
REKLAM HARCAMALARININ FİRMA KARLILIK PERFORMANSINA ETKİSİ ${ }^{1}$ \\ THE EFFECT OF ADVERTISING EXPENDITURES ON COMPANY PROFITABILITY PERFORMANCE
}

\author{
Mesut ASLAN ${ }^{2}$ \\ Müslüm POLAT ${ }^{3}$
}

$\ddot{O} \mathbf{z}$

$\mathrm{Bu}$ çalışmada BIST imalat sektöründe faaliyet gösteren firmaların reklam harcamalarının firma Karlılık performansına etkisi panel veri analizi ile araştırılmıştır. Araştırma da firma performansını temsilen toplamda üç model oluşturulmuştur. 2010-2019 dönemi boyunca imalat sektöründe reklam harcaması yapan 43 firma verisi ile analizler gerçekleştirilmiştir. Analiz sonuçlarına göre reklam harcamalarının firmaların satışlarının karlılığını ve faaliyet karlılığını negatif etkilediği ve anlamlı olduğu, aktiflerin karlılığına etkisinin ise anlamlı olmadığ1 tespit edilmiştir. Firmalara ait birim etkiler incelendiğinde; reklam harcamalarının firmalara etkisinin firmadan firmaya farklılık gösterdiği, bazı firmaların reklam harcamalarından olumlu, bazı firmaların ise olumsuz etkilendiği belirlenmiştir.

Anahtar Kelimeler: Reklam Harcamaları, BİST İmalat Sektörü, Panel Veri Analizi, Firma Performansı Jel Kodlari: G0, G17,M37

\begin{abstract}
In this study, the effect of advertising expenditures on the firm profitability performance of companies operating in the BIST manufacturing sector was investigated by panel data analysis. Three different models were created to represent the firm performance. Analyzes were carried out between 2010-2019 with the data of 43 companies that spent advertising in the manufacturing sector in the corresponding period. According to the results, advertising expenditures negatively affected the profitability of sales and operating profitability of the companies, but the effect on the profitability of assets was not statistically significant unit effects of the companies showed that the effect of advertising expenditures on companies differs from company to company, some companies are effected positively and some companies are effected positively and some are negatively effected by advertising expenditures.
\end{abstract}

Keywords: Advertising Expenditures, BIST Manufacturing Sector, Panel Data Analysis, Firm Performance Jel Codes: G0, G17,M37

\footnotetext{
${ }^{1}$ Bu çalışma Mesut Aslan'ın Doç. Dr. Müslüm Polat danışmalığında yaptığı "Reklam Harcamalarının Firma Performansına Etkisi: BİST İmalat Sektöründe Panel Veri Analiziyle Bir Uygulama" adlı doktora tezinden türetilmiştir.

${ }^{2}$ Arş. Gör., Bingöl Üniversitesi İktisadi ve İdari Bilimler Fakültesi İşletme Bölümü, mesutaslan@ @ingol.edu.tr, 0000-0003-2338-7474

${ }^{3}$ Doç. Dr., Bingöl Üniversitesi İktisadi ve İdari Bilimler Fakültesi İşletme Bölümü, mpolat@bingol.edu.tr, 00000003-1198-4693
} 


\section{GíRIŞ}

Reklam, firmaların ulaşmak istedikleri tüketiciyi, reklamı yapılan ürün veya hizmete yönelik reklam mesajını anlamaya, firma tarafından sunulan satış vaadini kabul ederek, tüketicide satın alma arzusu oluşturup, hedef tüketicileri satın alma davranışına yöneltmeyi amaçlar. Günümüzde reklam, firmaların en çok önem verdiği ve çok az anlaşılan firma harcamalarının başında gelmektedir (Graham ve Frankenberger, 2000: 149). Özellikle piyasaların sıkıntılı olduğu dönemlerde firmaların önem vermesi gereken önemli harcamalardan biri olarak görülmektedir. Bu nedenden dolayı, reklam harcamaları ve bu harcamaların firmalara olan getirisi eski dönemlerde olduğu gibi, günümüzde de araştırmacıların merak ettiği konulardan biri olmuştur (Geyikçi ve Mucan, 2016: 69).

Reklam kavramının insanlar arasında yayılışı, alışverişin yapılmasıyla beraber olmuştur. Bununla birlikte modern teknolojik araçların yayılması reklamcılığın önemini daha da artırmıştır. M.Ö. 3000'li yıllarda tüccarların ve çığırtkanların satış yapmak amacıyla dükkânlarının önlerinde açmış oldukları tabelalar reklamcılık tarihinin ilk örnekleri olarak kabul edilmektedir (Deniz, 2008: 129).

Antik çağlardan beri reklam gibi tanıtım araçlarına yazı, sembol ve çizime dayalı medeniyete sahip olan tüm topluluklarda rastlamak mümkündür. Reklamın başlangıç tarihi çok eskilere dayanıyor olmasına rağmen, bugün anladığımız anlamda reklamın ilk kullanılmış örneklerine Ortaçağ Avrupa'sında rastlamak mümkündür. Bu çağlarda, ilk dönemlerde okuryazar insan sayısı çok az ve bu yüzden satıcılar tıpkı tellallar gibi yüksek sesle bağırarak satmış oldukları ürünlere dikkat çekmeye çalışmışlardır. Bu tanıtım yöntemi, 1450 yıllarından itibaren matbaanın icat edilmesiyle yazılı, çizimsel ve resmedilmiş bir duyuru aracı olan afişler, tanıtım yazıları gibi değişik iletişim araçlarıyla ortaya konulmuştur (Çetin, 2014: 562).

Medyadaki teknolojik ilerlemenin bir sonucu olarak, reklam endüstrisi 20. ve 21. Yüzylllarda inanılmaz bir değişim geçirmiştir. Gazete reklamcılığının altın çağı 1890-1920 arasındaydı. 1920'lerden bu yana, radyo yayını gittikçe artan bir şekilde gazeteleri işlerini yeniden değerlendirmeye zorladı ve aynı şey 1950 'de Procter gibi tanınmış şirketler medyada ortaya çıktığında reklamlar geliştirilmeye başlandı (Esteban Bravo, Vidal-Sanz ve Yıldırım, 2015: 306).

Ülkemizde reklamcılık faaliyetlerinin Osmanlı döneminde başladığını söyleyebiliriz. XV. Yüzyılda Osmanlı Devleti'nde matbaaların tesis edilmesinden sonra matbaa kullanımı artmış ve 1828 y1lında Mısır Hidiv'i olarak adlandırılan Kavalalı Mehmet Ali Paşa tarafından Havadis-i Mısriyye adında ilk gazete matbaada basılarak yayınlanmıştır. 1831 yılında Takvim-i Vekayi çıkarılmış ve ardından 1860 yılında ilk özel gazete olan Tercüman-1 Ahval yayımlanmaya başlanmıştır. 1878 itibariyle gazete yayın sayısı artmış olmasına rağmen, I. Dünya Savaşı öncesinde İstanbul'da yayınlanan gazetelerin sayısı önemli oranda azalmıştır (Yılmaz, 2017: 261). 
Ülkemizde gerçek anlamda reklamcılık faaliyetleri incelendiğinde, dünya genelinde ilk basılan gazete reklamlarından bir hayli uzak olduğumuz görülmektedir. Reklamcıllk faaliyetlerine yönelik gelişmeleri ancak 19. yüzyıl ortalarına doğru görmek mümkündür. Osmanlı Devleti’nde 19. yüzyılın ilk yarısında Avrupa'ya kıyasla çok az bilinen reklamcılık faaliyeti ve çok az sayıda olan reklam ilanları, 1838 yılından itibaren ticari imtiyazları ve yoğun ticaret potansiyelini değerlendirmek isteyen batılı tüccarların etkisi ile önemli bir gelişme kaydetmiştir (Yardımcı, Genç ve Süloğlu, 2017: 87).

Piyasada var olan yüksek düzeydeki rekabet ortamı, firmaları ve pazarlamacıları yoğun rekabet içerisinde rakiplerinden daha avantajlı bir durumu elde etmeye ve rakiplerinden daha önde olabilme çabası içerisine sokmaktadır. Rekabet avantajı korumadığı durumda markaların varlıklarını devam ettirmeleri neredeyse imkansız bir hal almaktadır. Bu nedenle reklam ürün ve hizmetler için oldukça önemli bir konuma sahiptir (Bacik, Fedorka ve Simova, 2012: 315).

Reklam firmalar için çeşitli firsatlar oluşturmasının yanında, bir gider kalemi olarak işletmelerin finansal tablolarında yer almaktadır. Piyasada faaliyette bulunan firmaların, özellikle uluslararası pazarlara açılabilmeleri için reklam konusuna önem vermeleri gerekmektedir. Firma yöneticileri, yapacakları reklam harcamaları sayesinde hem firmaların gelecekteki performansına ilişkin bilgiler verecek, hem de yatırım yapacak olan yatırımcılara ileriye yönelik bir işaret vermiş olacaklardır. Dolayısıyla, reklam harcamaları, firmaların ileride elde edeceği getiriyi ve firmanın değerini önemli ölçüde etkileyecektir (Graham and Frankenberger, 2000: 154). Bu çalışmanın odak noktası reklam harcamalarının firmaların karlılık performansına olan etkilerinin belirlenmesidir. $\mathrm{Bu}$ çalışmanın odak noktasında, birim değişkenler olarak satışlar, aktifler ve faaliyet karlılıkları esas alınarak reklam harcamalarının firma performansına etkisi analiz edilmiştir.

\section{LITERATÜR TARAMASI}

Rekabetin git gide önemini arttırdığı son yıllarda, reklam günümüz ekonomik yaşamın en önemli iletişim araçlarından olmuştur. Özellikle medya araçlarının çeşitliliğinden dolayı, reklam farklı alanlara kaysa da, firmaların reklam harcamaları her geçen gün artmaktadır. Yapılan Literatür araştırmasında reklam harcamalarının firmaların performansı üzerindeki etkisinin bazı çalışmalar da pozitif, bazı çalışmalarda da negatif olduğu sonucu tespit edilmiştir. İlgili literatür özet olarak Tablo 1 'de verilmiştir. 
Tablo1. Literatür Taramas1

\begin{tabular}{|c|c|c|c|c|}
\hline Yazarlar & $\begin{array}{c}\text { Araştırma yapılan } \\
\text { Alan/ } \\
\text { Ülkeler }\end{array}$ & Yöntem & Dönem & Sonuç \\
\hline $\begin{array}{l}\text { Paton ve } \\
\text { Williams } \\
\text { (1999) }\end{array}$ & $\begin{array}{l}\text { İngiltere' deki } 325 \\
\text { firma }\end{array}$ & $\begin{array}{l}\text { En Küçük } \\
\text { Kareler } \\
\text { Yöntemi }\end{array}$ & $\begin{array}{l}\text { 1991-1992- } \\
1993 \\
\text { Aylik Veri }\end{array}$ & $\begin{array}{l}\text { Esas olarak tüketim malları } \\
\text { endüstrilerin'de faaliyet gösteren şirketler } \\
\text { için reklamın karlılıkla ilişkili olduğu } \\
\text { bulunmuştur. Reklam harcamasının firma } \\
\text { performansına olumlu bir etki yaptığı } \\
\text { tespit edilmiştir. }\end{array}$ \\
\hline $\begin{array}{l}\text { Kim ve Morris } \\
\text { (2003) }\end{array}$ & $\begin{array}{l}\text { ABD'deki Super bowl } \\
\text { reklamları }\end{array}$ & $\begin{array}{l}\text { Havuzlanmış En } \\
\text { Küçük Kareler } \\
\text { Yöntemi }\end{array}$ & $\begin{array}{l}1998,1999 \text { ve } \\
2000 \\
\text { Aylik Veri }\end{array}$ & $\begin{array}{l}\text { Zirve reklam döneminde olan şirketler ele } \\
\text { alınarak reklam ve firma performansı } \\
\text { arasındaki ilişki araştırılmaya çalışılmıştır. } \\
\text { Reklam harcamalarının firmaların piyasa } \\
\text { değeri üzerinde anlamlı bir etkisinin } \\
\text { olmadığı tespit edilmiştir. }\end{array}$ \\
\hline $\begin{array}{l}\text { Çitak } \\
(2015)\end{array}$ & $\begin{array}{c}\text { Borsa İstanbul KOBİ } \\
\text { sanayi endeksine } \\
\text { kayitlı firmalar }\end{array}$ & $\begin{array}{l}\text { Veri Zarflama } \\
\text { Yöntemi }\end{array}$ & $\begin{array}{l}\text { 2012-2013 } \\
\text { Günlük ve } \\
\text { Haftalık Veri }\end{array}$ & $\begin{array}{l}\text { Reklam harcamalarının finansal } \\
\text { performans üzerindeki etkisi ve borsa } \\
\text { İstanbul KOBİ sanayi endeksi firmalarının } \\
\text { etkinlikleri değerlendirilmiştir. KOBİ'lerin } \\
\text { reklam harcamalarının genel olarak düşük } \\
\text { olduğu ve çoğunun ölçeğe göre artan } \\
\text { getiride faaliyet gösterdiği sonucuna } \\
\text { ulaşılmıştır }\end{array}$ \\
\hline $\begin{array}{l}\text { Qureshi } \\
\text { (2007) }\end{array}$ & $\begin{array}{l}\text { İngiltere'de Faaliyette } \\
\text { Bulunan Firmalar }\end{array}$ & $\begin{array}{l}\text { Engle Granger } \\
\text { Eş-bütünleşme } \\
\text { testi }\end{array}$ & $\begin{array}{l}\text { 1998-2003 } \\
\text { Aylık Veri }\end{array}$ & $\begin{array}{l}\text { Firmaların reklam harcamaları ile firma } \\
\text { değeri artışları arasında pozitif bir ilişki } \\
\text { olduğu belirlenmiştir. }\end{array}$ \\
\hline $\begin{array}{l}\text { Koçoğlu ve } \\
\text { Haşıloğlu } \\
\text { (2008) }\end{array}$ & $\begin{array}{l}\text { Türkiye İstatistik } \\
\text { Kurumu (TÜİK)' e } \\
\text { kayıtlı } 3 \text { Dijitli } 260 \\
\text { Sektör }\end{array}$ & $\begin{array}{l}\text { Veri zarflama } \\
\text { ve korelasyon } \\
\text { yöntemi }\end{array}$ & $\begin{array}{l}\text { 1993-2001 } \\
\text { Haftalık Veri }\end{array}$ & $\begin{array}{l}\text { Reklam harcamalarının firmaların etkinlik } \\
\text { seviyeleri üzerinde önemli ölçüde bir } \\
\text { etkisinin olduğu tespit edilmiştir. }\end{array}$ \\
\hline $\begin{array}{l}\text { Altın } \\
(2010)\end{array}$ & $\begin{array}{l}\text { İMKB'ye kayitlı } 142 \\
\text { şirket }\end{array}$ & $\begin{array}{l}\text { Klasik en küçük } \\
\text { kareler yöntemi }\end{array}$ & $\begin{array}{l}31 \text { Aralık } \\
2008 \text { Bilanço } \\
\text { Dönemi }\end{array}$ & $\begin{array}{l}\text { Reklam harcamaları etkin kullanıldığında } \\
\text { şirketin piyasa değerinin artacağı ve } \\
\text { dolayısıyla reklam harcaması ile şirketin } \\
\text { piyasa değeri arasında pozitif yönlü ve } \\
\text { anlamlı bir ilişki olduğu sonucu elde } \\
\text { edilmiştir. }\end{array}$ \\
\hline $\begin{array}{l}\text { Peterson ve } \\
\text { Jeong } \\
\text { (2010) }\end{array}$ & $\begin{array}{c}\text { Standard\&Poors } \\
\text { Compustant PC-Plus } \\
\text { veri atabnındaki } 125 \\
\text { Firmadan toplamda } \\
848 \text { firma yılı gözlemi }\end{array}$ & Varyans Analizi & $\begin{array}{l}\text { 1991-2007 } \\
\text { Yillık Veri }\end{array}$ & $\begin{array}{l}\text { Reklam harcamalarının kurumsal marka } \\
\text { değeri ve firma düzeyinde firma } \\
\text { performansı üzerinde etkisinin olumlu } \\
\text { olduğu sonucu elde edilmiştir. }\end{array}$ \\
\hline $\begin{array}{l}\text { Joshi ve } \\
\text { Hanssens } \\
\text { (2010) }\end{array}$ & $\begin{array}{l}\text { Compustat-CRSP-I / } \\
\mathrm{B} \text { / E / S birleştirilmiş } \\
\text { veri tabanındaki } \\
\text { firmalar }\end{array}$ & $\begin{array}{l}\text { Fama French üç } \\
\text { faktör modeli }\end{array}$ & $\begin{array}{l}\text { 1975-2009 } \\
\text { Yillık Veri }\end{array}$ & $\begin{array}{l}\text { Reklam harcamalarının kendi firmalarının } \\
\text { piyasa değeri üzerinde olumlu ve uzun } \\
\text { vadeli bir etkisinin olduğu, } \\
\text { karşı̧laştırılabilir büyüklükteki rakip } \\
\text { değerlemesi üzerinde olumsuz bir etkisinin } \\
\text { olduğu sonucu elde edilmiștir. }\end{array}$ \\
\hline
\end{tabular}




\begin{tabular}{|c|c|c|c|c|}
\hline $\begin{array}{l}\text { Gür ve } \\
\text { Bayraktar } \\
(2011)\end{array}$ & $\begin{array}{l}\text { İMKB'ye kayitlı } 23 \\
\text { firma }\end{array}$ & $\begin{array}{l}\text { En Küçük } \\
\text { Kareler } \\
\text { Yöntemi }\end{array}$ & $\begin{array}{l}\text { 2003-2008 } \\
\text { Günlük Veri }\end{array}$ & $\begin{array}{l}\text { Reklamin finansal geri dönüş üzerine } \\
\text { pozitif etkisi olduğu tespit edilmiştir. }\end{array}$ \\
\hline $\begin{array}{l}\text { Luo ve jong } \\
\qquad \text { (2012) }\end{array}$ & $\begin{array}{l}\text { CRSP ve Compustat' } \\
\text { ta yer alan Nyse-, } \\
\text { Amex-, Nasdaq } \\
\text { listesindeki tüm } \\
\text { menkul kiymetler }\end{array}$ & $\begin{array}{l}\text { Newly-West } \\
\text { sağlam } \\
\text { regresyon } \\
\text { yöntemi }\end{array}$ & $\begin{array}{l}\text { 1987-2006 } \\
\text { Y1llık Veri }\end{array}$ & $\begin{array}{l}\text { Reklam harcamalarının firma getirisi } \\
\text { üzerindeki etkisi net olarak ortaya } \\
\text { konulmamış ve kısmen bir etkisinin olduğu } \\
\text { tespit edilmiştir. }\end{array}$ \\
\hline $\begin{array}{c}\text { Sridhar, } \\
\text { Narayanan ve } \\
\text { Srinivasan } \\
\text { (2013) }\end{array}$ & $\begin{array}{l}\text { ABD'deki } 903 \\
\text { endüstriyel firmanın } \\
6.815 \text { gözlemini } \\
\text { içermektedir }\end{array}$ & $\begin{array}{c}\text { Satış sezgisel } \\
\text { yüzdesi yöntemi }\end{array}$ & $\begin{array}{l}1990-2011 \\
\text { Y1ll1k Veri }\end{array}$ & $\begin{array}{l}\text { Reklam harcamalarının firma performansı } \\
\text { üzerinde uzun vadeli bir etkisinin olduğu } \\
\text { tespit edilmiştir. }\end{array}$ \\
\hline $\begin{array}{l}\text { A.Saeed, } \\
\text { Hwang ve } \\
\text { Grover } \\
\text { (2014) }\end{array}$ & $\begin{array}{l}\text { Japonya'daki } 52 \text { B2 } \\
\text { şirketi üzerinde } \\
\text { araştırma yapılmıştır. }\end{array}$ & Faktör Analizi & $\begin{array}{l}\text { 199-2001 } \\
\text { Günlük Veri }\end{array}$ & $\begin{array}{l}\text { Tek başına reklam harcamalarının firma } \\
\text { performansı üzerinde yalnızca ihmal } \\
\text { edilebilir bir etkisi olduğu tespit edilmiştir. } \\
\text { Firmaların daha uygun bir performans } \\
\text { stratejisi için reklam harcamalarını müşteri } \\
\text { satın alma deneyiminden elde ettiği değeri } \\
\text { artıran üstün bir alışveriş deneyimi ile } \\
\text { tamamlamaları ile mümkün olabileceği } \\
\text { sonucu elde edilmiştir. }\end{array}$ \\
\hline $\begin{array}{l}\text { Assaf, } \\
\text { Josiassen } \\
\text { Matilla ve } \\
\text { Knezevic } \\
\text { (2015) }\end{array}$ & $\begin{array}{l}\text { Slovenya ve } \\
\text { Hirvatistan' daki } \\
\text { Oteller }\end{array}$ & $\begin{array}{l}\text { Dinamik } \\
\text { Stokastik Sınır } \\
\text { Yaklaşımı, }\end{array}$ & $\begin{array}{l}\text { 20007-2012 } \\
\text { Aylık Veri }\end{array}$ & $\begin{array}{l}\text { Reklam harcamalarının otel satış } \\
\text { performansı üzerinde olumlu bir etkisinin } \\
\text { olduğu ve daha büyük oteleler ve daha } \\
\text { yüksek yıldız derecelendirmesine sahip } \\
\text { oteller için ilişkinin güçlendiğini tespit } \\
\text { edilmiștir. }\end{array}$ \\
\hline
\end{tabular}

Çalışmanın literatüre birçok yönden katkı sağlaması beklenmektedir. Önemli katkılardan biri Türkiye'de reklam gibi finansal olarak ölçülmesi zor olan bir araştırma alanıyla ilgili az miktarda yapılmış olan çalışmalara katkı sağlayacak olmasıdır. Bu çalışmayla reklam harcamalarının satışların karlılığına, aktif karlılığına ve faaliyet karlılığına ne yönde bir etkisinin olduğu analiz edilmektedir. İmalat sanayinde faaliyette bulunan firmalar üzerinden elde edilen verilerle reklamın firma performansına etkisi ortaya konularak, firmaların reklam harcaması politikalarının ne yönlü olması gerektiği belirlenmeye çalışılacaktır.

\section{VERİ VE YÖNTEM}

Ekonometrik analizlerde yaygın olarak kullanılan veri türlerinden biri olan panel veri, belirli bir dönemde, ülke, firma, birey, hane halkları gibi birimlere ait yatay kesit gözlemlerin bir araya getirilmesi olarak tanımlanmaktadır. Hem dönemlere hem de birimlere göre bilgilerin elde edilmesine imkan veren panel veri, $\mathrm{N}$ sayıda ve her birime karşılık gelen $\mathrm{T}$ sayıda gözlemden oluşmaktadır. $\mathrm{Bu}$ doğrultuda, panel verilerin kullanılması sonucunda oluşturulmuş olan modellerin, ekonomik ilişkilerin tahmininde kullanılması yöntemine "Panel Veri Analizi” denilmektedir (Tatoğlu, 2012: 2). 
Panel veri analizinin genel olarak kabul görmüş klasik regresyon denklemi 1 numaralı eşitlik yardımıyla formüle edilmektedir:

$$
Y i t=\alpha+\beta X i t+\varepsilon i t
$$

Yukarıda belirtilen eşitlikte $Y_{\text {it }}$ bağımlı değişkeni, $\alpha$ sabit değişim katsayısını, $\beta$ eğim katsayılarını, $X_{\text {it }}$ açıklayıcı değişkenler setini ve $\varepsilon_{\text {it }}$ hata terimleri vektörünü ifade etmektedir. i modelde yer alan kesit sayısını $(\mathrm{i}=1, \ldots, \mathrm{n})$ ve $\mathrm{t}$ her kesite ait zaman uzunluğunu $(\mathrm{t}=1, \ldots, \mathrm{T})$ belirtmektedir.

Panel veri analizinin son dönemlerde yaygın bir şekilde kullanılmasının temel sebeplerinden biri, panel veri analizinde verilerin daha fazla bulunması, ayrıca yalnızca yatay kesit veya yalnızca zaman serisi verilerinden sonuç alınamayan problemlerde analizlere yönelik istenen sonuçları göstermesidir. Araştırmanın sadece yatay kesit verilerinden meydana gelmesi durumunda N sayıda gözlemden oluşmaktadır. Aynı şekilde araştırmanın sadece zaman serisi verilerinden meydana gelmesi durumunda T sayıda gözlem bulunması demektir. Panel veri analizinde belirtilmiş olan bu iki tip veri bir araya geldiğinde NxT adet gözlem elde edilmektedir. Dolayıyla panel veri analizi, yatay kesit ve zaman serisi verilerine oranla daha fazla gözlem sayısına sahip olmaktadır. Bu durum, analizlere yönelik gözlem sayısını ve serbestlik derecesini de arttırmaktadır (Tatoğlu, 2012: 9).

Genel olarak panel veri denklemi aşağıda yer alan 2 numaralı eşitlik ile ifade edilmektedir (Akınc1, Yüce ve Y1lmaz, 2014: 87):

$$
\mathrm{Y}_{\mathrm{it}}=\beta_{1}+\beta_{2} \mathrm{X}_{2 \mathrm{it}}+\beta_{3} \mathrm{X}_{3 \mathrm{it}}+\varepsilon_{\mathrm{it}}
$$

(2) numaralı denklem de tüm bağımsız değişkenlerin, yatay kesit birimlerinin tümünü aynı derecede etkilediğini göstermektedir. Aksine olan bir durumda ise belirtilen denklem yetersiz kalmaktadır. Burada ortaya çıkan önemli bir konu, başlangıç noktasının nasıl tanımlanacağıdır. Başlangıç noktası, tüm birimler için sabit olabileceği gibi, farklı birimler için farklı başlangıç noktalarının olmasına da izin verilebilir. Dikkate alınan kısıtlar neticesinde, sabit ve tesadüfi etkili modeller olmak üzere iki yöntem ortaya çıkmaktadır. Başlangıç noktasının tüm yatay kesit birimleri için farklı sabit bir değer alacağını savunan sabit etkili model, (3) numaralı eşitlik ile ifade edilmektedir (Akınc1, Yüce, ve Yılmaz, 2014 : 87):

$$
\mathrm{Y}_{\mathrm{it}}=\beta_{2 \mathrm{i}} \mathrm{X}_{2 \mathrm{it}}+\beta_{3 \mathrm{i}} \mathrm{X}_{3 \mathrm{it}}+\varepsilon_{\mathrm{it}}
$$

Belirtilen eşitlikte yer alan hata terimi ve açıklayıcı değişkenler arasında bir ilişkinin söz konusu olması durumunda, sabit etkiler modelinin kullanılması daha doğru bir karar olacaktır. Çünkü bu durumda sabit etkiler modelinin tahmincileri sapmasız olmaktadır.

Başlangıç noktasını rassal değişken olarak tanımlamış olan tesadüfi etkiler modeline göre, başlangıç noktaları $\beta_{1}$ sabit değeri ile sıfır ortalamalı $\mu_{\mathrm{i}}$ rassal değişkeninin toplamından meydana gelmekte ve (4) numaralı eşitlik ile ifade edilmektedir (Akıncı, Aktürk ve Yılmaz: 6): 


$$
\mathrm{Y}_{\mathrm{it}}=\beta_{1 \mathrm{i}}+\beta_{2 \mathrm{i}} \mathrm{X}_{2 \mathrm{it}}+\beta_{3 \mathrm{i}} \mathrm{X}_{3 \mathrm{it}}+\varepsilon_{\mathrm{it}}, \quad \beta_{1 \mathrm{j}} \neq \beta_{1 \mathrm{i}}+\mu_{\mathrm{i}}
$$

(4) numaralı denklemde belirtilen Rassal etkili (random effects) model de, kesitlere ya da zamana bağlı olarak oluşan değişiklikler, modele hata teriminin bir bileşeni olarak dahil edilmeleri durumunda söz konusu olur. Rassal etkili modellerde serbestlik derecesi kaybı ortadan kalkmış olmasından dolayı sabit etkili modellere göre daha üstündür. Ayrıca rassal etkiler modeli, modele örneklemin dışında yer alan etkilerin de dahil edilmesine firsat tanımaktadır (Kaya ve Abay, 2020: 90).

Hausman testi, sabit etkili ve rassal etkili tahmincileri arasında anlamlı bir fark olup olmadığını test etmeyi sağlar. Hausman, yokluk hipotezi ile $\left(\mathrm{H}_{0}: \mathrm{E}\left(\mu_{\mathrm{it}} / \mathrm{X}_{\mathrm{it}}\right)=0\right) \mathrm{X}_{\mathrm{it}}$ ve $\mu_{\mathrm{i}}$ arasında ilişkinin bulunmadığını tespit eden bir test geliştirmiştir. Hausman testinin amacı, sabit ve rassal etkiler tahmincilerinden hangisinin kullanılacağı karar vermektir. Sabit etkiler tahmincisi (GIT) hem yokluk hipotezi hem de alternatif hipotez altında tutarlı olurken, rassal etkiler tahmincisi (GEKK) yalnızca yokluk hipotezi altında tutarlı ve etkin olmaktadır (Karabulut ve Şeker, 2018, s.92).

$\mathrm{Bu}$ çalışmadaki veri setinin hazırlanmasında kullanılan finansal tablolar, 2010-2019 yılları arası Kamuyu Aydınlatma Platformuna kayıtlı imalat sektörlerinin dipnotlarından alınmıştır. Firma değerleri ise Finnet2000 programından elde edilmiştir. Daha sonra bir araya getirilen finansal tablolardan gerekli oranlar hesaplanmıştır. Hesaplanan bu değişkenler; bağımlı, bağımsız ve kontrol değişkenleri şeklinde üç gruba ayrılmıştır. Bu değişkenleri belirleyebilmek amacıyla benzer çalışmalar incelenmiş (Geyikçi ve Mucan, 2016; Qureshi, 2007; Baltagi, 1999). reklam harcamalarının etkisini belirlemek amacıyla yapılan çalışmalardan bağımsız değişkene karar verilmiştir. Ardından firma performansına yönelik yapılmış olan çalışmalardan, firma performansını temsil edebilecek oranlar tespit edilerek bağımlı değişkenler belirlenmiş ve son olarak panel veri analizi kullanarak reklam harcamalarının firma performansına etki düzeyini araştıran çalışmalardan uygun görülen kontrol değişkenleri tespit edilmiştir.

Çalışmanın yapıldığı zaman itibariyle imalat sektöründe toplamda 173 firma faaliyet göstermektedir ve bu firmalardan yalnızca 43 tanesi ilgili dönem boyunca reklam harcaması yapmıştır. Dolayısıyla çalışmada bu 43 firmaya ait veriler kullanılmıştır.

Modellerde kullanılan Bağımlı, bağımsız ve kontrol değişkenleri ile bunların kısaltma ve açıklamaları Tablo 2'de belirtilmiştir. Değişkenlerden sadece Satışların Logaritması değişkeni logaritmik bir veridir. Modellerde yer alacak diğer bütün değişkenler oran şeklindedir. 
Tablo 2. Değişkenler ile Değişkenlerin Kisaltmaları

\begin{tabular}{|c|c|c|c|}
\hline & Değişkenin Adı & $\begin{array}{l}\text { Değişkenin } \\
\text { Kısaltması }\end{array}$ & Değişkenin Açıklaması \\
\hline \multicolumn{4}{|c|}{ Bağımlı Değişkenler } \\
\hline 1 & Satışların Karlılı̆̆ & SA_KA & Net kar satış hasılatına bölünmüştür. \\
\hline 2 & Aktiflerin Karlılı̆g 1 & AK_KA & Net kar aktiflerin toplamına bölünmüştür. \\
\hline 3 & Faaliyet Karlılığ1 & FA_KAM & Faaliyet karı satış hasılatına bölünmüştür. \\
\hline \multicolumn{4}{|c|}{ Bağımsız Değişken } \\
\hline 1 & Reklam Harcamaları/Satışlar & RE_HAR & $\begin{array}{l}\text { Reklam harcamaları satış hasılatına } \\
\text { bölünmüştür }\end{array}$ \\
\hline \multicolumn{4}{|c|}{ Kontrol Değişkenleri } \\
\hline 1 & Satışların Logaritması & SA_LOG & Satış hasılatının logaritması alınmıştır. \\
\hline 2 & Kaldıraç Oranı & KAL_OR & Toplam borç toplam aktiflere bölünmüştür. \\
\hline
\end{tabular}

Analizlere öncelikli olarak değişkenlere ait tanımlayıcı istatistikler hesaplanarak başlanılmıştır ve ardından değişkenler arasındaki korelasyon katsayıları hesaplanmıştır. Panel veri analizinde serilerin durağanlığını test etmeden önce, birimler arasında yatay kesit bağımlılığının var olup olmadığı test edilir. Eğer Serilerde yatay kesit bağımlılığı yoksa birinci nesil birim kök testlerini, yatay kesit bağımlılı̆̆ 1 varsa ikinci nesil birim kök testlerini kullanmak daha tutarlı sonuçlar elde etmemizi sağlayacaktır (Polat, 2016, s.130). Bu amaçla öncelikli olarak değişenlerde yatay kesit bağımlılığının varlığ1 Breusch-Pagan LM (Breusch ve Pagan), Pesaran Scaled LM (Pesaran, 2004), Bias Corected Scaled LM (Bun ve Carree, 2005) ve Pesaran CD (Pesaran, 2004) testleri ile test edilmiş ve serilerde yatay kesit bağımlılı̆̆ının var olduğu tespit edilmiştir. Yatay kesit bağımlılığının varlığından dolayı değişkenler ikinci nesil birim kök testlerinden Panic (Boing) testi ile sınanmış ve değişkenlerin durağan oldukları saptanmıştır.

Serilerin durağanlığ test edildikten sonra modeller sırasıyla incelenmeye başlanmış. Seriler durağan olduklarından modeller panel EKK (En Küçük Kareler Yöntemi ) ile tahmin edilecektir. Modeller tahmin edilmeden önce söz konusu modelde sabit ve rassal etkilerin var olup olmadığının araştırılması gerekir. Bu amaçla sabit etkinin ve rassal etkinin var olup olmadığını belirlemek amacıyla sırasıyla F testi (Fisher, 1963) ve Honda LM (Honda, 1985) testi kullanılmıştır. Modelde sabit ve rassal etkilere rastlanıldığı zaman, sabit etkili model ve rassal etkili model den hangisinin kullanılacağına karar vermek amacıyla Hausman testi (Hausman, 1978) uygulanmıştır.

Modele karar verildikten sonra tahmin sonuçlarının güvenilir sonuçlar verebilmesi için modelde değişen varyans, otokorelasyon ve birimler arası korelasyon sorununun bulunmaması gerekmektedir. Bu amaçla değiş̧en varyansın varlığı sabit birim etkiler modelinde Wald testi ile (Enders, 2003), rassal birim etkiler modelinde Levene-Brown-Forsthe testi ile (Levene, 1960), otokorelasyonun varlığı sabit birim etkiler modelinde Baltagi-wu LBI testi ile (Baltagi, 1999), rassal 
birim etkiler modelinde Durbin Watson testi (Durbin ve Watson, 1950) ve Baltagi-wu testi ile, birimler arası korelasyonun varlığı ise Pesaran testi ile sınanmıştır. Modelde değişen varyans, otokorelasyon ve birimler arası korelasyonun bulunması durumunda gerekli düzenlemeler yapılarak model tahmin edilmiştir.

Çalışmada kullanılacak modeller şu şekildedir:

$\underline{\text { Satıșların Karlılığı İçin Geliștirilen Model }}$

$$
\mathrm{SA} \_K A=\mathrm{a}_{\mathrm{i}}+\beta_{1} \mathrm{RE} \_\mathrm{HAR}+\beta_{2} \mathrm{SA} \_\mathrm{LOG}_{\mathrm{i}, \mathrm{t}}+\beta_{3} \mathrm{KAL} \_\mathrm{OR}_{\mathrm{i}, \mathrm{t}}+\varepsilon_{\mathrm{i}, \mathrm{t}}
$$

\section{$\underline{\text { Aktiflerin Karlılığ } 1 \text { İçin Geliștirilen Model }}$}

$$
\mathrm{AK} \_\mathrm{KA}=\mathrm{a}_{\mathrm{i}}+\beta_{1} \mathrm{RE} \_\mathrm{HAR}+\beta_{2} \mathrm{SA} \_\mathrm{LOG}_{\mathrm{i}, \mathrm{t}}+\beta_{3} \mathrm{KAL} \_\mathrm{OR}_{\mathrm{i}, \mathrm{t}}+\varepsilon_{\mathrm{i}, \mathrm{t}}
$$

Faaliyetlerin Karlılığı İçin Geliștirilen Model

$$
\mathrm{FA} \_K A M=a_{i}+\beta_{1} R E \_H A R+\beta_{2} S A \_L O G_{i, t}+\beta_{3} K_{-} A L \_O R_{i, t}+\varepsilon_{i, t}
$$

Modellerde bağımsız değişken RE_HAR (Reklam harcamaları/Satışlar)'dır. Kontrol değişkenleri ise SA_LOG (Satışların Logaritması) ve KAL_OR (Kaldıraç Oranı) şeklindedir.

\section{ANALIZ VE BULGULAR}

Tablo 3 incelendiğinde 43 firmanın reklam harcamalarının satışlara oranının ortalaması $\% 15$ 'dir. Bu durum firmalarımızın reklam harcamalarına az bir bütçe ayırdıklarını göstermektedir. Örneğin dünyanın en büyük reklam veren firmalardan biri olan Procter\& Gamble 2015 yılında bütçesinin yaklaşık olarak \%19.1 'ini reklam harcamalarına ayırarak, 4.6 milyon dolarlık bir reklam harcaması yapmıştır. Yine benzer şekilde General Motors, Ford Motor Company gibi şirketlerde reklam harcamasına büyük pay ayıran şirketlerdendir (www.businessinsider.com, Erişim tarihi, 06.03.2021). Büyüme oranlarının pozitif olması ilgili dönemde genel olarak firmaların büyüdügünü göstermektedir. Ayrıca normallik testi olan Jarqua-Bera (Jarque, 1981) istatistiğine göre değişkenlerin

\begin{tabular}{|c|c|c|c|c|c|c|c|c|}
\hline Değişkenler & Ortalama & Median & Maximum & Minimum & $\begin{array}{c}\text { Standart } \\
\text { sapma }\end{array}$ & Skewness & $\begin{array}{c}\text { Jarque- } \\
\text { Bera }\end{array}$ & $\begin{array}{c}\text { Olasılık } \\
\text { (Gözlem } \\
\text { Sayısı) }\end{array}$ \\
\hline RE_HAR & 0.0152 & 0.0059 & 0.1923 & 0.000 & 0.0225 & 2.6762 & 2615.612 & $\begin{array}{c}0.0000 \\
(430)\end{array}$ \\
\hline SA_KA & 0.0328 & 0.0345 & 0.7296 & -0.3734 & 0.0985 & 0.3764 & 1335.25 & $\begin{array}{c}0.0000 \\
(430)\end{array}$ \\
\hline AK_KA & 3.4169 & 3.165 & 30.67 & -19.6 & 6.7373 & -0.2210 & 32.9992 & $\begin{array}{c}00000 \\
(430)\end{array}$ \\
\hline FA_KAM & 5.7584 & 6.000 & 35.72 & -19.28 & 7.1192 & 0.2079 & 66.2748 & $\begin{array}{c}0.0000 \\
(430)\end{array}$ \\
\hline SA_LOG & 8.7225 & 8.6065 & 10.95 & 6.9506 & 0.7482 & 0.6456 & 31.1809 & $\begin{array}{c}0.0000 \\
(430)\end{array}$ \\
\hline KAL_OR & 52.8301 & 54.610 & 10.58 & 6.060 & 22.1433 & -0.0539 & 23.9355 & $\begin{array}{c}0.0000 \\
(430)\end{array}$ \\
\hline
\end{tabular}
tümü normal dağılım göstermemektedir.

Tablo 3. İmalat Sektöründeki Değişkenlere Ait Tanımlayıcı İstatistikler 
İmalat sektörüne yönelik yapılacak analizlerde kullanılacak bütün değişkenlere ait korelasyon katsayıları Tablo 4'te verilmiştir. İstatiksel anlamda korelasyon katsayısı 1 ile -1 arasında bir değer alır. Değişkenler arasındaki korelasyon katsayısının işareti ilişkinin yönünü belirtir. Mutlak değer olarak katsayının, bire yakın olması durumunda güçlü bir ilişki var olduğunu gösterirken, sıfıra yakın olması ise zayıf bir ilişki olduğunu ifade etmektedir.

Tablo 4. İmalat Sektöründeki Değişkenlere Ait Korelasyon Katsayıları

\begin{tabular}{lcccccc}
\hline & RE_HAR & SA_KA & AK_KA & FA_KAM & SA_LOG & KAL_OR \\
\hline RE_HAR & 1 & & & & & \\
SA_KA & -0.182 & 1 & & & & \\
AK_KA & -0.192 & 0.847 & 1 & & & \\
FA_KAM & -0.126 & 0.532 & 0,544 & 1 & & \\
SA_LOG & -0.167 & 0.104 & 0.313 & 0.158 & 1 & \\
KAL_OR & 0.099 & -0.303 & -0.306 & 0.148 & 0.359 & 1 \\
\hline
\end{tabular}

Tablo 4'e bakıldığında bağımsız değişken olarak kullanılacak olan reklam harcamaları değişkeni ile diğer bütün değişkenler arasında zayıf ilişki olduğu görülmektedir. Reklam harcamaları/satış gelirleri değişkeninin kaldıraç oranı değişkeni dışındaki diğer bütün değişkenlerle negatif yönlü bir ilişkiye sahip olduğu dikkat çekmektedir.

Ayrıca reklam harcamaları/satış gelirleri değişkeninin diğer değişkenlerle ilişkisi incelendiğinde en kuvvetli ilişkinin satışların karlılığı değişkeni ile (-0.192) ile en zayıf ilişkinin ise kaldıraç oranı (0.099) ile olduğu görülmektedir.

Modellerde bağımsız değişken olarak reklam harcamaları, kontrol değişkeni olarak ta satışların logaritması ve kaldıraç oranı kullanılmıştır. Bağımsız ve kontrol değişkenleri arasında zayıf bir ilişki olduğu tablo 4' ten anlaşılmaktadır. Aktiflerin karlılığ ile satışların karlılığı (0.847) arasında yüksek derecede bir ilişki, faaliyet karlılığı ile satışların karlılığı (0.532), faaliyet karlılığı ile aktiflerin karlıllğ 1 (0.544) arasında orta derecede bir ilişki olduğu görülmektedir. Ancak bu değişkenlerin tümü birbirinden ayrı modellerde ele alınacağı için çoklu doğrusal bağlantı hatasına sebep olması mümkün değildir.

Panel veri analizi yapılırken dikkat edilmesi gereken en önemli konulardan bir tanesi, birimler arasında yatay kesit bağımlılı̆̆ının var olup olmadığının test edilmesi gerektiğidir. Yatay kesit bağımlılı̆̆ı ihmal edilirse, panel veri analizinde bazı çarpıklıklar ve bozulmalar meydana gelmektedir (Alataş ve Peker, 2016: 65). Yatay kesit bağımlılık testi sonucunda eğer değişkenler arasında yatay kesit bağımlılığı yoksa birinci nesil birim kök testleri kullanılırken, değişkenler arasında yatay kesit bağımlılı̆̆ varsa ikinci nesil birim kök testleri kullanmak daha etkili sonuçlar verecektir. Bu nedenle serilerin durağanlığını test etmeden önce değişkenlerde yatay kesit bağımlılı̆̆ Breusch Pegan LM, Pesaran Scaled LM ve Bias-Corected Scaled LM testleri ile test edilmiş ve sonuçlar Tablo 5'te verilmiştir. 
Tablo 5. İmalat Sektörü İçin Yatay Kesit Bağımlılı̆̆g Test Sonuçları

\begin{tabular}{|c|c|c|c|c|}
\hline Değişkenler & Breusch-Pagan LM & Pesaran Scaled LM & $\begin{array}{c}\text { Bias Corrected scaled } \\
\text { LM }\end{array}$ & $\begin{array}{c}\text { Pesaran } \\
\text { CD }\end{array}$ \\
\hline RE_HAR & $\begin{array}{l}1661.93^{*} \\
(0.0000)\end{array}$ & $\begin{array}{c}17.85^{*} \\
(0.0000)\end{array}$ & $\begin{array}{c}15.46^{*} \\
(0.0000)\end{array}$ & $\begin{array}{c}5.52 * \\
(0.0000)\end{array}$ \\
\hline SA_KA & $\begin{array}{l}166.90 * \\
(0.0000)\end{array}$ & $\begin{array}{c}8.56^{*} \\
(0.0000)\end{array}$ & $\begin{array}{c}6.17 * \\
(0.0000)\end{array}$ & $\begin{array}{c}1.14 \\
(0.2513)\end{array}$ \\
\hline AK_KA & $\begin{array}{l}156.74 * \\
(0.0000)\end{array}$ & $\begin{array}{c}8.32 * \\
(0.0000)\end{array}$ & $\begin{array}{c}5.93 * \\
(0.0000)\end{array}$ & $\begin{array}{c}0.38 \\
(0.7029)\end{array}$ \\
\hline FA_KAM & $\begin{array}{l}110.02 * \\
(0.0000)\end{array}$ & $\begin{array}{c}16.63^{*} \\
(0.0000)\end{array}$ & $\begin{array}{c}14.24 * \\
(0.0000)\end{array}$ & $\begin{array}{c}11.43^{*} \\
(0.0000)\end{array}$ \\
\hline SA_LOG & $\begin{array}{l}650.53 * \\
(0.0000)\end{array}$ & $\begin{array}{l}133.59 * \\
(0.0000)\end{array}$ & $\begin{array}{l}131.20^{*} \\
(0.0000)\end{array}$ & $\begin{array}{c}72.81 * \\
(0.0000)\end{array}$ \\
\hline KAL_OR & $\begin{array}{l}257.62 * \\
(0.0000)\end{array}$ & $\begin{array}{c}38.69^{*} \\
(0.0000) \\
\end{array}$ & $\begin{array}{c}36.31^{*} \\
(0.0000) \\
\end{array}$ & $\begin{array}{c}23.27 * \\
(0.0000) \\
\end{array}$ \\
\hline
\end{tabular}

Yapılan testler sonucunda yatay kesit bağımlılığının olmadığını savunan $\mathrm{H}_{0}$ hipotezi Breusch pegan LM, Pesaran Scaled LM ve Bias-Corected Scaled LM testlerine göre \%1 önem seviyesinde reddedilmiştir. Yani bu testler sonucunda bütün birimler arasında yatay kesit bağımlı̆̆ 1 vardır. Dolayısıyla değişkenlerin durağanlığı, yatay kesit bağımlılı̆̆ını dikkate alan ikinci nesil birim kök testi ile test edilecektir.

Tablo 6. İmalat Sektörü İçin İkinci Nesil Birim Kök Testleri

\begin{tabular}{|c|c|c|c|c|}
\hline \multirow{3}{*}{ DEĞİŞKENLER } & \multicolumn{4}{|c|}{ PANIC (BOING) } \\
\hline & \multicolumn{2}{|c|}{ SABİTLİ } & \multicolumn{2}{|c|}{ SABİTLİ VE TRENDLİ } \\
\hline & PCe_Choi & PCe_MW & PCe_Choi & PCe_MW \\
\hline \multirow[t]{2}{*}{ RE_HAR } & $5.9895 *$ & $164.5522^{*}$ & $6.0207 *$ & $164.9603^{*}$ \\
\hline & $(0.0000)$ & $(0.0000)$ & $(0.0000)$ & $(0.0000)$ \\
\hline \multirow[t]{2}{*}{ SA_KA } & $6.7010 *$ & $173.8836^{*}$ & $6.1984 *$ & $167.2913 *$ \\
\hline & $(0.0000)$ & $(0.0000)$ & $(0.0000)$ & $(0.0000)$ \\
\hline \multirow[t]{2}{*}{ AK_KA } & $4.5799 *$ & $146.0654 *$ & $7.3887 *$ & $182.9020 *$ \\
\hline & $(0.0000)$ & $(0.0001)$ & $(0.0000)$ & $(0.0000)$ \\
\hline \multirow[t]{2}{*}{ FA_KA_M } & $3.7730 *$ & $135.4827 *$ & $4.5924 *$ & $146.2287 *$ \\
\hline & $(0.0001)$ & $(0.0005)$ & $(0.0000)$ & $(0.0001)$ \\
\hline \multirow{2}{*}{ SA_LOG } & $2.5922 *$ & $119.9963 *$ & $5.2823 *$ & $155.2763 *$ \\
\hline & $(0.0048)$ & $(0.0091)$ & $(0.0000)$ & $(0.0000)$ \\
\hline \multirow[t]{2}{*}{ KAL_OR } & $5.6071 *$ & $159.5361 *$ & $4.3322 *$ & $142.8158 *$ \\
\hline & $(0.0000)$ & $(0.0000)$ & $(0.0000)$ & $(0.0000)$ \\
\hline
\end{tabular}

Yatay kesit bağımlılığının varlığından dolayı yapılan ikinci nesil birim kök testinden Panic (Boing) testine ait değişkenlerin sonuçları Tablo 6'da verilmiştir. Yapılan Panic (Boing) ikinci nesil birim kök testleri sonucunda \%1 önem seviyesinde hiçbir değişkenin birim kök içermediği yani bütün serilerin düzey değerleri I(0) ile durağan oldukları tespit edilmiştir.

Reklam harcamalarının satışların karlılığına etkisini ölçmek için hazırlanan model (1)'de açıklayıcı değişken olarak reklam harcamaları (reklam harcamaları/satışlar) ve kontrol değişkeni olarak SA_LOG (satışların logaritması) ile KAL_OR (Kaldıraç Oranı) serilerinden yararlanılmıştır. 


$$
\text { SA_KA }=\beta_{1} \text { RE_HAR }+\beta_{2} S A \_L O G_{i, t}+\beta_{3}+K A L \_O R_{i, t}+\varepsilon_{i, t}
$$

Model (1) deki sabit etkileri ve rassal etkileri test etmek amacıyla kullanılan F ve HONDA LM testinin sonuçları Tablo 7'de verilmiştir.

Tablo 7. Model (1) için F, LM ve Hausman Test Sonuçları

\begin{tabular}{lccl}
\hline \multicolumn{1}{c}{ Testler } & İstatistik & Olasılık & \multicolumn{1}{c}{ Sonuç } \\
\hline $\mathbf{F}_{\text {Birim }}$ & $3.429^{*}$ & 0.0000 & Birim Etkisi var \\
$\mathbf{F}_{\text {Zaman }}$ & $15.650^{* * *}$ & 0.0745 & Zaman etkisi var \\
$\mathbf{F}_{\text {Birim-Zaman }}$ & $149.332^{*}$ & 0.0000 & Birim-Zaman Etkisi var \\
\hline $\mathbf{L M}_{\text {Birim }}$ & $35.160^{*}$ & 0.0000 & Birim Etkisi var \\
$\mathbf{L M}_{\text {Zaman }}$ & 0.0000 & 1.0000 & Zaman Etkisi Yok \\
$\mathbf{L M}_{\text {Birim-Zaman }}$ & $35.441^{*}$ & 0.0000 & Birim-Zaman Etkisi var \\
\hline Hausman & 3.6310 & 0.3042 & Rassal Etkili Model \\
\hline Not: \%1, \%5 ve \%10 Önem seviyelerindeki anlamlıl1k, sirası ile *,**,*** ile ifade edilmiştir. \\
\hline
\end{tabular}

Model (1)'in tahmininde dirençli tahmincilere ihtiyaç olup olmadığını tespit edebilmek amacıyla değişen varyansın test edilmesi için kullanılan Levene-Brown-Forsthe testi, otokorelasyonun test edilmesi için kullanılan LM ve ALM testi ve birimler arası korelasyonun test edilmesi amacıyla kullanılan Pesaran testi sonuçları Tablo 8'de sunulmuştur.

Tablo 8. Model (1) İçin Değişen Varyans, Otokorelasyon ve Birimler Arası Korelasyon Test Sonuçları

\begin{tabular}{ccc}
\hline Testler & İstatistik & Olasılık \\
\hline Levene-Brown-Forsthe & $5.304 *$ & 0.0000 \\
LM ve ALM & $75.53^{*}$ & 0.0000 \\
Pesaran Testi & $2.292^{* *}$ & 0.0219 \\
\hline Not: \%1, \%5, \%10 önem seviyelerindeki anlamlılık sırası ile $* * *, * * *$ ile ifade edilmiştir.
\end{tabular}

Tablo 8'de Lewene-Brown-Forsthe testine göre \%1 önem seviyesinde değişen varyansın olmadığını savunan $\mathrm{H}_{0}$ hipotezi, LM ve ALM testine göre \%1 önem seviyesinde otokorelasyonun olmadığını savunan $\mathrm{H}_{0}$ hipotezi, Pesaran testine göre birimler arası korelasyonun olmadığını savunan $\mathrm{H}_{0}$ hipotezi reddedilmiştir. Yani bu durumda hem değişen varyans, hem otokorelasyon hem de birimler arası korelasyon sorunu vardır. Dolayısıyla tek yönlü rassal etkili model dirençli tahmincilerden Driscoll-Kraay tahmincisi (Driscoll ve Kraay, 1998) ile tahmin edilecektir.

Tablo 9. Model (1) İçin Rassal Etkili Regresyon Sonuçları

\begin{tabular}{lcccc}
\hline \multicolumn{1}{c}{ Değişkenler } & Katsayı & Standart Hata & t-İstatistiği & Olasılık \\
\hline RE_HAR & $-0.637 *$ & 0.148 & -4.28 & 0.002 \\
SA_LOG & $0.030^{*}$ & 0.0054 & 5.55 & 0.000 \\
KAL_OR & $-0.0018^{*}$ & 0.0003 & -5.09 & 0.001 \\
$\mathbf{C}$ & $-0.1220 * *$ & -0.0508 & -2.40 & 0.040 \\
\hline $\mathbf{R}^{2}=0.7550$ & $\mathbf{F}=0.0000$ & & \\
\hline Not: $\% 1, \% 5$ ve $\% 10$ önem seviyelerindeki anlamlilık, sirası ile *, ** ve *** ile ifade edilmiştir.
\end{tabular}


Yapılan regresyon analizi sonucuna göre bütün katsayılar \%1 anlam düzeyinde anlamlıdır. Reklam harcamalarındaki bir puanlık artış satışların karlılığını 0.637 puan azaltmaktadır. Satışlardaki bir puanlık artış satışların karlılığını 0.030 puan artırmaktadır. Kaldıraç oranındaki bir puanlık artış satışların karlılığını 0.0018 puan azaltmaktadır.

Araştırmamızda, 43 firmaya ait veriler kullanılarak yapılan analizlerde elde edilen panel sonuçlarından bağımsız olarak, reklam harcamalarının satışların karlılığına her bir firma için etkisine de ayrıca bakmak gerekmektedir. Çünkü her firmanın reklam harcamasına verdiği önem ile reklam harcamasına yapmış olduğu yatırım farklı olmaktadır.

Tablo 10. Model (1) İçin Firmalara Ait Birim Etkiler

\begin{tabular}{llcllc}
\hline Sıra & \multicolumn{1}{c}{ Firmalar } & Katsayı & Sıra & \multicolumn{1}{c}{ Firmalar } & Katsayı \\
\hline 1 & Ford & -0.0070 & 23 & Deva & 0.0360 \\
2 & Karsan & -0.0508 & 24 & Aygaz & -0.0445 \\
3 & Anadolu Isuzu & -0.0067 & 25 & Ege Profil & 0.0632 \\
4 & Tofaş & 0.0151 & 26 & Good Year & -0.0125 \\
5 & Vestel & -0.0176 & 27 & Hektaş & 0.0843 \\
6 & Alarko & -0.0041 & 28 & Sarkuysan & -0.0195 \\
7 & Parsan & 0.0024 & 29 & Bossa & 0.0111 \\
8 & Arçelik & -0.0067 & 30 & Desa Deri & 0.0005 \\
9 & İhlas & -0.0382 & 31 & Akın Tekstil & 0.0256 \\
10 & Klimasan & 0.0519 & 32 & Yataş & 0.0471 \\
11 & Ersu & -0.0226 & 33 & Yünsa & 0.0217 \\
12 & Kent & 6.2900 & 34 & Viking & -0.0556 \\
13 & Pınar et-un & 0.0032 & 35 & Ege Seramik & 0.0334 \\
14 & Pınar Su & -0.0284 & 36 & Doğtaş & 0.0235 \\
15 & Pınar Süt & 0.0029 & 37 & Uşak Seramik & 0.0156 \\
16 & Banvit & -0.0066 & 38 & Afyon Çimento & -0.0024 \\
17 & Kristal & -0.0556 & 39 & Bursa Çimento & -0.0063 \\
18 & Tat Gıda & 0.0004 & 40 & Çemaş Döküm & -0.0856 \\
19 & Brisa & 0.0385 & 41 & Katmerciler & 0.0356 \\
20 & Dyo Boya & 0.0213 & 42 & Dagi Giyim & 0.0041 \\
21 & Marshall & -0.0290 & 43 & Hateks & -0.0206 \\
22 & Tüpraş & -0.0171 & & & \\
\hline
\end{tabular}

İmalat sektöründe faaliyet gösteren ve ilgili dönemde kesintisiz reklam harcaması yapan firmadan 21'inin yaptığı reklam harcamalarının satışların karlılığına olumlu, 22'sinin ise olumsuz yansıdığı görünmektedir. Olumlu yansıyanlar arasında en çok etkinin (6.2900) kent gıda maddeleri firmasında olduğu görünmektedir. Kent gıdadan sonra en yüksek olumlu etkinin Hektaş Ticaret firmasında (0.0843), en düşük olumlu etkinin ise Parsan Makina Parçaları firmasında (0.0024) olduğu Tablo 4' de anlaşılmaktadır. Negatif yönlü en yüksek etkinin Kristal ( -0.0556) ve en düşük etkinin ise Afyon Çimento'da (-0.002) olduğu görünmektedir.

Reklam harcamalarının aktiflerin karlılığına etkisini ölçmek için hazırlanan model (2)'de açıklayıcı değişken olarak Reklam harcamaları (Reklam harcamaları/Satışlar) ve kontrol değişkenleri olarak SA_LOG (Satışların logaritması) ile KAL_OR (Kaldıraç Oranı) serilerinden yararlanılmıştır.

$$
\mathrm{AK} \_\mathrm{KA}=\mathrm{a}_{\mathrm{i}+} \beta_{1} \mathrm{RE} \_\mathrm{HAR}+\beta_{2} \mathrm{SA} \_L_{\mathrm{LOG}}+\beta_{3, \mathrm{~K}} \mathrm{KAL} \_\mathrm{OR} \mathrm{R}_{\mathrm{i}, \mathrm{t}} \varepsilon_{\mathrm{i}, \mathrm{t}}
$$


Modeldeki Sabit etkileri test etmek amacıyla kullanılmış olan F testi ile rassal etkileri test etmek amacıyla kullanılan Honda LM testi ve bu iki testten hangisinin kullanılacağına karar verebilmek amacıyla kullanılan Hausman testinin sonuçları Tablo 11'de görünmektedir.

Tablo 11. Model (2) İçin F, LM ve Hausman Test Sonuçları

\begin{tabular}{lccl}
\multicolumn{1}{c}{ Testler } & İstatistik & Olasılık & \multicolumn{1}{c}{ Sonuç } \\
\hline $\mathbf{F}_{\text {Birim }}$ & $5.5795^{*}$ & 0.0000 & Birim Etkisi Var \\
$\mathbf{F}_{\text {Zaman }}$ & $20.822^{* *}$ & 0.0135 & Zaman Etkisi Var \\
$\mathbf{F}_{\text {Birim-Zaman }}$ & $219.045^{*}$ & 0.0000 & Birim-Zaman Etkisi Var \\
\hline $\mathbf{L M}_{\text {Birim }}$ & $78.563^{*}$ & 0.0000 & Birim Etkisi Var \\
$\mathbf{L M}_{\text {Zaman }}$ & 0.002 & 0.484 & Zaman Etkisi Yok \\
$\mathbf{L M}_{\text {Birim-Zaman }}$ & $79.761^{*}$ & 0.0000 & Birim-Zaman Etkisi Var \\
\hline Hausman & $4.357^{*}$ & 0.0000 & Sabit Ekili Model \\
\hline Not: \%1,\%5, \%10 önem seviyelerindeki anlamlılık, sirası ile *,***** ile ifade edilmiștir. \\
\hline
\end{tabular}

Sabit ve rassal etkilerin var olup olmadığını test etmek amaciyla yapılan F ve LM testleri sonucunda, sabit birim etkilerin ve rassal birim etkilerin varlı̆g $1 \% 1$ önem düzeyinde anlamlı, sabit zaman etkilerinin varlığı \%5 önem düzeyinde anlamlı bulunurken, rassal zaman etkisi anlamlı çıkmamıştır. $\mathrm{Bu}$ durumda sabit etkili model ve rassal etkili modelleden hangisinin kullanılacağına karar vermek amacıyla hausman testi yapılmıştır. Hausman testine göre rassal etkilerin olduğunu iddia eden $\mathrm{H}_{0}$ hipotezi reddedilmiştir. Dolayısıyla sabit etkili model kullanılacaktır.

Model (2)'in tahmininde dirençli tahmincilere ihtiyaç olup olmadığını tespit edebilmek amacıyla değişen varyansın test edilmesi için kullanılan Wald testi, otokorelasyonun test edilmesi için kullanılan Baltagi-Wu LBI testi ve birimler arası korelasyonun test edilmesi amaciyla kullanılan Pesaran testi sonuçları Tablo 12'de sunulmuştur.

Tablo 12. Model (2) İçin Değişen Varyans, Otokorelasyon ve Birimler Arası Korelasyon Test Sonuçları

\begin{tabular}{ccc}
\hline Testler & İstatistik & Olasılık \\
\hline Wald Testi & $159.62^{*}$ & 0.0000 \\
Baltagi-Wu Lbı & $1.6654^{*}$ & 0.0000 \\
Pesaran Test & $2.151^{* *}$ & 0.0315 \\
\hline Not: $\% 1, \% 5, \% 10$ önem seviyelerindeki anlamlılık, sirası ile ***,*** ile ifade edilmiştir.
\end{tabular}

Tablo 11'deki Wald testine testine göre \%1 önem seviyesinde değişen varyansın olmadığını savunan H0 hipotezi reddedilmiştir. Baltagi-Wu LBI testine göre \%1 önem seviyesinde otokorelasyonun olmadığını savunana H0 hipotezi reddedilmiştir. Pesaran testine göre birimler arası korelasyonun olmadığını savunan H0 hipotezi reddedilmiştir. Yani bu durumda hem değişen varyans, hem otokorelasyon hemde birimler arası korelasyon sorunu vardır. Dolayısıyla çift yönlü sabit etkili model dirençli tahmincilerden Driscoll ve Kraay tahmincisi ile tahmin edilecektir. 
Tablo13. Model (2) İçin Sabit Etkili Regresyon Sonuçları

\begin{tabular}{lcccc}
\hline \multicolumn{1}{c}{ Değişkenler } & Katsayı & Standart Hata & t-İstatistiği & Olasılık \\
\hline RE_HAR & -38.5470 & 26.7682 & -1.44 & 0.184 \\
SA_LOG & $4.1358 *$ & 1.1648 & 3.55 & 0.006 \\
KAL_OR & $-0.1957 *$ & 0.0272 & -7.20 & 0.000 \\
$\mathbf{C}$ & $-21.731 * *$ & 8.9138 & -2.44 & 0.037 \\
\hline $\mathbf{R}^{2}=0.1538$ & $\mathbf{P = 0 . 0 0 0 1}$ & & \\
\hline Not: $\% 1, \% 5$ ve \%10 önem seviyelerindeki anlamlılık, sirası ile *, ** ve *** ile ifade edilmiştir. \\
\hline
\end{tabular}

Yapılan regresyon analizi sonucuna göre reklam harcamaları ve satışların logaritması arasında anlamlı bir ilişki bulunmamıştır. Satışlardaki bir puanlık artış aktiflerin karlılı̆̆ını 4.1358 puan artırmaktadır. Kaldıraç oranındaki bir puanlık artış aktiflerin karlılığını -0.1957 puan azaltmaktadır.

Araştırmamızda, 43 firmaya ait veriler kullanılarak yapılan analizlerde elde edilen panel sonuçlarından bağımsız olarak, reklam harcamalarının satışların karlılığına her bir firma için etkisine de ayrıca bakmak gerekmektedir. Çünkü her firmanın reklam harcamasına verdiği önem ile reklam harcamasına yapmış olduğu yatırım farklı olmaktadır.

Tablo 14. Model (2) İçin Firmalara Ait Birim Etkiler

\begin{tabular}{llcclc}
\hline Sıra & Firmalar & Katsayı & Sıra & Firmalar & Katsayı \\
\hline 1 & Ford & 1.0201 & 23 & Deva & 1.0190 \\
2 & Karsan & -1.5384 & 24 & Aygaz & -2.5006 \\
3 & Anadolu Isuzu & -0.4902 & 25 & Ege Profil & 1.5521 \\
4 & Tofaş & 1.7049 & 26 & Good Year & 1.4638 \\
5 & Vestel & -1.5193 & 27 & Hektaş & 2.5527 \\
6 & Alarko & 0.1140 & 28 & Sarkuysan & -1.0225 \\
7 & Parsan & -1.5631 & 29 & Bossa & 0.8382 \\
8 & Arçelik & -1.3427 & 30 & Desa Deri & 0.4511 \\
9 & İlas & -1.6967 & 31 & Akın Tekstil & -2.1497 \\
10 & Klimasan & 1.0542 & 32 & Yataş & 0.5859 \\
11 & Ersu & -0.7865 & 33 & Yünsa & 1.3468 \\
12 & Kent & -1.6623 & 34 & Viking & -4.2774 \\
13 & Pinar et-un & 0.7412 & 35 & Ege Seramik & 1.6307 \\
14 & Pinar su & -1.2100 & 36 & Doğtaş & 1.7999 \\
15 & P1nar süt & 0.3964 & 37 & Uşak Seramik & 1.6047 \\
16 & Banvit & -0.7002 & 38 & Afyon Çimento & -1.2202 \\
17 & Kristal & -1.8528 & 39 & Bursa Çimento & -0.9099 \\
18 & Tat Gida & 1.2473 & 40 & Çemaş Döküm & -4.3552 \\
19 & Brisa & 1.8927 & 41 & Katmerciler & 1.8585 \\
20 & Dyo Boya & 1.5299 & 42 & Dagi Giyim & 0.4568 \\
21 & Marshall & -2.1821 & 43 & Hateks & \\
22 & Tüpraş & -1.4305 & & & \\
\hline
\end{tabular}


İmalat sektöründe faaliyet gösteren ve ilgili dönemde kesintisiz reklam harcaması yapan firmadan 22'sinin yapmış olduğu reklam harcamalarının aktiflerin karlılığına etkisi olumlu, 21'inin ise olumsuz yansıdığı görünmektedir. Olumlu yansıyanlar arasında en çok etkinin Hektaş Ticaret A.Ş. firmasında (2.5527) olduğu görünmektedir. Hektaş firmasından sonra en yüksek olumlu etki, Brisa Bridgestone Sabancı Lastik Sanayi ve Ticaret A.Ş. firmasına (1.8927) aittir. En düşük olumlu etkinin ise Alarko Carrier A.Ş.'d firmasında (0.1140) olduğu Tablo 3.14'ten anlaşılmaktadır. Negatif yönlü en yüksek etkinin ise Viking firmasında ( -4.277) ve en düşük etkinin ise Anadolu Isuzu firmasında ( -0.4902) olduğu görünmektedir.

Reklam harcamalarının faaliyet karlılı̆̆ına etkisini ölçmek için hazırlanan model 3'te açıklayıcı değişken olarak RE_HAR (Reklam harcamaları/Satışlar) ve kontrol değişkenleri olarak SA_LOG (Satışların logaritması) ile KAL_OR (Kaldıraç Oranı) serilerinden yararlanılmıştır.

$F A \_K A M=a_{i}+\beta_{1} R E \_H A R+\beta_{2} S A \_L O G_{i, t}+\beta_{3} K_{-} A L \_O R_{i, t}+\varepsilon_{i, t}$

Modeldeki Sabit etkileri test etmek amacıyla kullanılmış olan F testi ile rassal etkileri test etmek amacıyla kullanılan Honda LM testinin sonuçları Tablo 15'te verilmiştir.

Tablo 15. Model (3) İçin F, LM ve Hausman Test Sonuçları

\begin{tabular}{lccl}
\hline \multicolumn{1}{c}{ Testler } & İstatistik & Olasilık & \multicolumn{1}{c}{ Sonuç } \\
\hline $\mathbf{F}_{\text {Birim }}$ & $11.7360^{*}$ & 0.0000 & Birim Etkisi Var \\
F Zaman & $28.1365^{*}$ & 0.0009 & Zaman Etkisi Var \\
F $_{\text {Birim-Zaman }}$ & $38.1996^{*}$ & 0.0000 & Birim-Zaman Etkisi Var \\
\hline LM $_{\text {Birim }}$ & $191.103^{*}$ & 0.0000 & Birim Etkisi Var \\
LM $_{\text {Zaman }}$ & $6.715^{*}$ & 0.005 & Zaman Etkisi Var \\
LM $_{\text {Birim-Zaman }}$ & $27.674^{*}$ & 0.0000 & Birim-Zaman Etkisi Var \\
\hline Hausman & $11.911^{* * *}$ & 0.0949 & Rassal Etkili Model \\
\hline Not: \%1, \%5 ve \%10 önem seviyelerindeki anlamlllık, sirası ile *, ** ve *** ile ifade edilmiştir.
\end{tabular}

Sabit ve rassal etkilerin var olup olmadığını test etmek amacıyla yapılan F ve LM testleri sonucunda, sabit birim etkilerin, sabit zaman etkilerinin, rassal birim etkilerinin ve rassal zaman etkilerinin varlığ $\% 1$ önem düzeyinde anlamlı bulunmuştur. Bu durumda sabit etkili model ve rassal etkili modelden hangisinin kullanılacağına karar vermek amacıyla hausman testi yapılmıştır. Hausman testine göre rassal etkilerin olduğunu iddia eden $\mathrm{H}_{0}$ hipotezi kabul edilmiştir. Dolayısıyla rassal etkili model kullanılacaktır.

Model 3'ün tahmininde dirençli tahmincilere ihtiyaç olup olmadığını tespit edebilmek amacıyla değişen varyansın test edilmesi için kullanılan Levene-Brown-Forsthe testi, otokorelasyonun test edilmesi için kullanılan LM ve ALM testi ve birimler arası korelasyonun test edilmesi amaciyla kullanılan Pesaran testi sonuçları tablo 16'da sunulmuştur. 
Tablo 16. Model (3) için Değişen Varyans, Otokorelasyon ve Birimler Arası Korelasyon Test Sonuçları

\begin{tabular}{ccc}
\hline Testler & Ístatistik & Olasılık \\
\hline Levene-Brown-Forsthe & $3.2462^{*}$ & 0.0000 \\
LM ve ALM Testi & $1.5593^{*}$ & 0.0000 \\
Pesaran Testi & $2.380^{* *}$ & 0.0173 \\
\hline Not: \%1, \%5 ve \%10 önem seviyelerindeki anlamlılık, sırası ile *,** ve *** ile ifade edilmiştir.
\end{tabular}

Tablo 16'da Wald testine göre \%1 önem seviyesinde değişen varyansın olmadığını savunan H0 hipotezi, reddedilmiştir. Baltagi-Wu LBI testine göre \%1 önem seviyesinde otokorelasyonun olmadığını savunana H0 hipotezi ve Pesaran testine göre birimler arası korelasyonun olmadığını savunan H0 hipotezi reddedilmiştir. Yani bu durumda hem değişen varyans, hem otokorelasyon hem de birimler arası korelasyon vardır. Dolayısıyla çift yönlü rassal etkili model dirençli tahmincilerden Driscoll-Kraay tahmincisi ile tahmin edilecektir.

Tablo17. Model (3) İçin Sabit Etkili Regresyon Sonuçları

\begin{tabular}{lcccc}
\hline Değişkenler & Katsayı & Standart Hata & t-İstatistiği & Olasılık \\
\hline RE_HAR & $-2.7607 * *$ & 1.0815 & -3.13 & 0.012 \\
SA_LOG & $1.6629 *$ & 0.5864 & 2.83 & 0.000 \\
KAL_OR & 0.0345 & 0.0326 & 1.06 & 0.317 \\
C & $-27.0655^{*}$ & 5.5934 & -4.84 & 0.001 \\
\hline $\mathrm{R}^{2}=0.6417$ & $\mathrm{P}=0.000$ & & \\
\hline Not: \%1, \%5 ve \%10 önem seviyelerindeki anlamlılık, sırası ile *, ** ve *** ile ifade edilmiştir.
\end{tabular}

Yapılan regresyon analizi sonucuna göre reklam harcamaları \%5 anlam düzeyinde ve satışların logaritması \%1 anlam düzeyinde anlamlı bulunmuştur. Reklam harcamalarındaki bir puanlık artış, faaliyet karlılığına -2.7607 puan azaltmaktadır. Satışlardaki bir puanlık artış faaliyet karlılığını 1.6629 puan artırmaktadır.

Tablo 18. Model (3) için Firmalara Ait Birim Etkiler

\begin{tabular}{clcclc}
\hline Sıra & \multicolumn{1}{c}{ Firmalar } & Katsayı & Sıra & Firmalar & Katsayı \\
\hline 1 & Ford & -4.0581 & 23 & Deva & 7.7269 \\
2 & Karsan & -6.6347 & 24 & Aygaz & -5.6556 \\
3 & Anadolu Isuzu & -3.2258 & 25 & Ege Profil & 3.5708 \\
4 & Tofaş & -2.7778 & 26 & Good Year & -1.1162 \\
5 & Vestel & -4.5289 & 27 & Hektaş & 15.9866 \\
6 & Alarko & 0.0317 & 28 & Sarkuysan & -6.3107 \\
7 & Parsan & 3.8881 & 29 & Bossa & 2.1858 \\
8 & Arçelik & -2.8308 & 30 & Desa Deri & -2.9334 \\
9 & Ihlas & -0.3911 & 31 & Akın Tekstil & -5.7660 \\
10 & Klimasan & 1.2637 & 32 & Yataş & 4.5545 \\
11 & Ersu & -1.9500 & 33 & Yünsa & 0.0236 \\
12 & Kent & -0.1074 & 34 & Viking & -3.4367 \\
13 & Pınar et-un & 2.3461 & 35 & Ege Seramik & 8.1646 \\
14 & Pınar Su & -4.0864 & 36 & Doğtaş & 3.9760 \\
15 & Pınar Süt & 0.8925 & 37 & Uşak Seramik & 6.1882 \\
16 & Banvit & -2.7089 & 38 & Afyon Çimento & -0.8237 \\
17 & Kristal & -4.4762 & 39 & Bursa Çimento & 1.5132 \\
18 & Tat Gıda & -0.8544 & 40 & Çemaş Döküm & -6.3792 \\
19 & Brisa & 4.2916 & 41 & Katmerciler & 9.8160 \\
20 & Dyo Boya & 3.2045 & 42 & Dagi Giyim & 3.5506 \\
21 & Marshall & -1.5445 & 43 & Hateks & -4.3544 \\
22 & Tüpraş & -6.2243 & & & \\
\hline
\end{tabular}

Araştırmamızda, 43 firmaya ait veriler kullanılarak yapılan analizlerde elde edilen panel sonuçlarından bağımsız olarak, reklam harcamalarının satışların karlılığına her bir firma için etkisine 
de ayrıca bakmak gerekmektedir. Çünkü her firmanın reklam harcamasına verdiği önem ile reklam harcamasına yapmış olduğu yatırım farklı olmaktadır.

İmalat sektöründe faaliyet gösteren ve ilgili dönemde kesintisiz reklam harcaması yapan firmadan 19'unun yaptığı reklam harcamalarının satışların karlılığına olumlu, 24'ünün ise olumsuz yansıdığı görünmektedir. Olumlu yansıyanlar arasında en çok etkinin Hektaş Ticaret A.Ş. firmasında (15.9866) olduğu görünmektedir. Hektaş Ticaret A.Ş firmasından sonra en yüksek olumlu etkinin Katmerciler Araç Üstü Ekipman Ticaret A.Ş. firmasında (9.8160) olduğu görülmektedir. En düşük olumlu etkinin ise Yünsa Yünlü Sanayi ve Ticaret A.Ş. firmasında (0.0236) olduğu Tablo 18'den anlaşılmaktadır. Negatif yönlü en yüksek etkinin Karsan Otomotiv Sanayi ve Ticaret A.Ş. firmasında ( -6.6347) ve en düşük etkinin ise Kent Gıda Maddeleri Sanayi ve Ticaret A.Ş. firmasında ( -0.1074) olduğu görünmektedir.

\section{SONUÇ}

Sürekli bir şekilde değişim ve gelişim gösteren günümüz dünyasında reklam, firmaların en yoğun olarak kullandığı iletişim araçlarından biridir. Reklamın doğasında yer alan bu değişim ve gelişimin temelinde, yaşanmış olan toplumsal ve teknolojik ilerlemelerin de payı vardır. Firmalar, içinde bulunduğu rekabet ortamında etkinliğini artırabilmek için çeşitli faaliyetlerde bulunmaktadır. Daha çok satış yapıp daha çok kazanmak isteyen firmalar reklam yaparak, firma karlılığını mümkün olduğunca maksimum yapmak isterler.

$\mathrm{Bu}$ çalışma, imalat sanayinde faaliyette bulunan firmaların reklam harcamalarının firma performansına etkisini belirlemek amacıyla yapılmıştır. Bu amaçla BİST’e kayıtlı imalat firmalarına ait veriler panel veri analizi kullanılarak tespit edilmeye çalışılmıştır. 2010-2019 yıllarında imalat sektöründe reklam harcaması yapmış olan toplamda 43 firma bulunmaktadır. Dolayısıyla bu firmalara ait veriler kullanılarak analiz yapılmıştır. Analiz sonuçlarına göre reklam harcamalarının firmaların satışların karlılığı ve faaliyet karlılığını negatif etkilediği, aktiflerin karlılığına etkisinin ise anlamlı olmadığı tespit edilmiştir. Firmalara ait birim etkiler incelendiğinde; reklam harcamalarının firmalara etkisinin firmadan firmaya farklılık gösterdiği, bazı firmaların reklam harcamalarından olumlu, bazı firmaların ise olumsuz etkilendiği belirlenmiştir.

Çalışmada kullanılan üç modele ait sonuçlar değerlendirildiğinde, reklam harcamalarının firma performansına olumlu bir etki yaptığı söylenemez. Çünkü ya negatif ya da anlamsız sonuçlar elde edilmiştir. Bu sonuçlar literatürde negatif etki bulan Kim ve Morris (2003), Joshi ve Hanses (2010) ve Luo ve Jong (2012) çalışmalarına paralellik göstermektedir. Bununla birlikte detaylı bir şekilde literatür çalışması yapıldığında reklam harcamalarının firma performansına etkisinin çoğunlukla pozitif olduğu görülmektedir. Oluşturulan modellerden elde edilen analiz sonuçlarına göre reklam harcamalarının firmaların satışların karlılığı ve faaliyet karlılığını negatif etkilediği, aktiflerin karlılığına etkisinin ise anlamlı olmadığı tespit edilmiştir. 
Reklam harcamalarının firma performansını pozitif etkileyememesinin en önemli nedenlerinden biri, reklam harcaması politikasının firmalar tarafindan doğru yürütülmüyor olmasından kaynaklanabilir. Çünkü doğru bir reklam politikası yürütüldüğünde, reklam harcaması performansı artıran bir yatırım aracı olarak firmaya yansır. Aksi takdirde getirisi olmayan bir gider olarak yansır. Modellerden elde edilen birim etkilere ait sonuçlarda bunu ispat etmektedir. Çünkü çalışmada kullanılan firmalara ait birim etkiler incelendiğinde bütün firmaların reklam harcamalarının firma performansını negatif etkilemediği görülecektir. Dolayısıyla reklam harcamalarına yönelik doğru bir politika yürüten firmaların reklam harcamalarının firma performansından pozitif etkilendiğini, doğru bir politika yürütmeyen firmaların ise negatif etkilendiğini söyleyebiliriz.

Reklam harcamalarının firma performansını pozitif etkileyememesinin bir başka nedeni firmaların sağlıkı bir pazarlama faaliyeti yürütmüyor olmasından kaynaklanabilir. Çünkü önemli bir pazara yönelik satış gerçekleştiren firmalar, doğru bir reklam anlayışıyla gelirlerini artırma ve karlılıklarını maksimum etme imkanı sağlarlar. Ancak, koordineli bir pazarlama anlayışı olmadığında reklam harcamalarından firmanın istediği performansı elde etme imkanı olmayacaktır.

\section{KAYNAKÇA}

Akınc1, M., Yüce, G. \& Yılmaz, Ö. (2014). Ekonomik Özgürlüklerin İktisadi Büyüme Üzerindeki Etkileri: Bir Panel Veri Analizi. Anadolu Üniversitesi Sosyal Bilimler Dergisi, 14(2), s.81-96.

Akıncı, M., Aktürk, E. \& Yılmaz, Ö. (2012). Petrol Fiyatları İle Ekonomik Büyüme Arasındaki İlişki: OPEC ve Petrol İthalatçısı Ülkeleri İçin Panel Veri Analizi. Uludă̆ Üniversitesi İktisadi ve İdari Bilimler Fakültesi Dergisi, 31(2), 1-17.

Alataş, S. \& Peker, O. (2016). Kurumsal Kalite ve Gelir: Panel Veri Analizi. Eskişehir Osmangazi Üniversitesi Sosyal Bilimler Dergisi, 17 (2), s.61-79.

Altın, H. (2010). Reklam Harcamalarının Şirketin Piyasa Değerine Olan Etkisi. H. ̈. İktisadi ve İdari Bilimler Fakültesi Dergisi, 1(28), s.59-69.

Assaf, G., Josiassen, A,, Matilla, A. \& Knezevic, L. (2015). Does Advertising Spending İmprove Sales Performance?. International Journal Of Hospitality Management, 48 (1), s.161-166.

Bacik, R., Fedorko, R. \& Simova, S.(2012). Advertising As a Tool Of Marketing Communication And İts Consequent İmpact On Consumers. Polish Journal of Management Studies, 5, s.299-306.

Baltagi, B. (1999). Unequally Spaced Panel Data Regressions With AR(1) Disturbances. Econometric Theory. 1(15), s.814-823.

Bera , J. (1981). Efficient Tests For Normality, Heteroskedasticity And Serial İndependence Of Regression Residuals: Monte Carlo evidence. Economics Letter, 7, 313 - 318. 
Breusch, T. \& Pagan, A. (1980). The Lagrange Multiplier Test and İts Applications to Model Specification in Econometrics. The Review of Economic Studies, 47 (1), s. 239-253.

Bun, M. \& Carree, M. (2005). Bias-corrected Estimation in Dynamic Panel Data Models. Journal of Business and Economic Statistics, 23 (1), s.200-210.

Çetin, B. (2014). Yeniden Anlamlandırma Aracı Olarak Reklam. Uluslararası Türk Veya Türk Dilleri, Edebiyatı ve Tarihi Dergisi, 9 (5), s.559-573.

Çıtak, L. (2015). Pazarlama Yatırımlarının Finansal Performans Üzerindeki Etkisi ve Borsa İstanbul Kobi Sanayi Endeksi Firmalarının Etkinliklerinin Değerlendirilmesi. Erciyes Üniversitesi İktisadi ve İdari Bilimler Fakültesi Dergisi, 0 (45), s.49-68.

Deniz, E. (2008), Markalaşma ve Reklam, 1.Baskı, İstanbul, Kum Saati Yayınları.

Driscoll, J. C. \& Kraay, A. C. (1998). Consistent Covariance Matrix Estimation With Spatially Dependent Panel Data, Review of Economics and Statistics, 80(4), s.549-560.

Durbin, J. \& Watson, G. (1950). Testing For Serial Corelation in Least Squares Regression, Biometrica, 1(37). s. 409-428

Enders, W. (2003). Applied Econometric Time Series. New York: John Wiley And Sons Inc.

Esteban-Bravo, V. \& Yıldırım, G. (2015). Historical İmpact Of Technological Change On The Us Mass Media Advertising Expenditure. Technological Forecasting\&Social Change, 100, s.306316.

Fisher, R. (1963). Sir Ronald Fisher and The Design of Experiments", International Biometric Society, 20 (2), s.307-321.

Geyikçi, U. \& Mucan, B. (2016). Reklam Harcamalarının Finansal Duruma Olan Etkisinin Panel Veri Analizi Yöntemiyle Ölçümü. Sosyal Bilimler Dergisi, 1(50), s.68-85.

Graham, R. \& Frankenber, K. (2000). The Contribution of Changes in Advertising Expenditures to Earnings and Market Values. Journal of Business Research, 50 (2), s.149-155.

Gür, F. \& Bayraktar, A. (2011). Reklamın Finansal Geri Dönüşü ve Bir Örnek Olay. Öneri Dergisi, 9 (35), s.127-141.

http://www.businessinsider.com/10-biggest-advertising-spenders-in-the-us-2015-7 (Erişim tarihi, 06.03.2021).

Hausman, J. (1978). Specification Tests in Econometrics. Econometrica. 0 (46), s.1251-1271.

Honda, Y. (1985). Testing the Error Components Model with Non-Normal Disturbances. Review of Economic Studies, 0 (52), s.681-690.

Jorion, P. (2007). Financial Risk Manager-Handbook. 3.Bask1, Garp yayınevi. 
Joshi, A. \& Hansens, D. (2010). The Direct and Endirect Effects of Advertising Spending on Firm Value. Sage Publication, 74 (1), s.20-33.

Kaya, İ. \& Abay, M. (2020). Türkiye İle Avrupa Birliği Üyesi 10 Ekonominin ARGE-Büyüme İlişkisi: Panel Veri Analizi. Anadolu Üniversitesi İktisadi ve İdari Bilimler Fakültesi Dergisi, 21 (2), s.81-95.

Karabulut, R., \& Şeker, K. (2018). Kar Payı Dağıtım Oranlarının Borçlanma Araçları Üzerinde Etkisi. Al-Farabi Uluslararası Sosyal Bilimler Dergisi, 2 (3), s.78-102.

Kim, J. \& Morris, J. (2003). The Effect of Advertising on The Market Value of Firms: Empirical Evidence From The Super Bowl Adds. Journal of Targeting, Measurement And Analysis for Marketing, 12, s. 53-65.

Koçoğlu, D. \& Haşıloğlu, S. (2008). Reklam Harcamalarının İşletmelerin Etkinlik Seviyesi Üzerindeki Etkisine Yönelik Bir Araştırma. Afyon Kocatepe Üniversitesi İ.I.B.F. Dergisi, 1(10), s.39-65.

Levene, H. (1960). Robust Tests for Equality of Variances. In Contributions to Probability and Statistics: Essays in honor of Harold Hotelling. Science And Education, (1) 2, s.278-292.

Luo, X. \& Jong, P. (2012). Does Advertising Spending Really Work? The İntermediate Role Of Analysts İn The İmpact Of Advertising On Firm Value. Journal Of The Academy Of Marketing Science, 40, s. 605-624.

Paton, D. \& Williams, L. (1999). Advertising and Firm Performance: Some New Evidence from UK Firms. Economic Issues, 4 (2), 89-105.

Pesaran, M. (2004). General Diagnostic Tests for Cross Section Dependence in Panels. University of Cambridge Working Paper, s.435.

Peterson, R. \& Jeong, J. (2010). Exploring the impact of advertising and R\&D expenditures on corporate brand value and firm-level financial performance. Original Empirlcal Research, 6(38), s.677-690.

Saeed, K., Hwang, Y. \& Grover, V. (2014). İnvestigating The İmpact Of Web Site Value And Advertising On Firm Performance İn Electronic Commerce. International Journal Of Electronic Commerce, 7 (2), s.119-141.

Sridhar, S., Narayanan, S. \& Srinivasan, R. (2013). Dynamic Relationships Among R\&D, Advertising, İnventory And Firm Performance. Pazarlama Bilimleri Dergisi, 42, s.277-290.

Tatoğlu, F. (2012). Panel Veri Ekonometrisi. 2. Bask1, İstanbul, Beta Basım Yayım.

Yardımcı, M., Genç, S.\& Süloğlu, D. (2017). Osmanlı Devleti’nde Reklamın Tarihsel Gelişimi ve Ekonomiye İlk Yansımaları. Sosyal Bilimler Metinleri,1, s.86-104. 
Yılmaz, R., (2017). Türkiye'de Reklam Anlatısının Dijital Çağdaki Yapısal Dönüşümü. 1.Uluslararası İletişimde Yeni Yönelimler Konferansı, İstanbul Teknik Üniversitesi, s.260-267.

Qureshi, İ. (2007). Advertising value of UK firms advertising expenditures. Global Journal of International Business Research, 1 (1), s.12-23. 